\title{
Nya trender och gamla mönster. \\ Doktorsavhandlingarna i socialt arbete 1980-2009
}

\author{
PETER DELLGRAN \& STAFFAN HÖJER
}

Doktorsavhandlingar har en speciell roll $i$ den akademiska kunskapsbildningen. Förutom att producera ny vetenskap-

lig kunskap återspeglar de i varierande grad inomdisciplinära traditioner, strömningar och forskningsfronter. I artikeln görs en kartläggning av former och innehaill $i$ samtliga doktorsavhandlingar $i$ socialt arbete fram $t o m$ ar 2009. Genomgången visar att vissa mönster består men också att nya tendenser gör sig gällande. Under 2000-talet ökade t.ex. inslaget av studier av sociala arbetsmetoder och sammanläggningsavhandlingar.

\section{Inledning}

Det har nu gått trettio år sedan socialt arbete blev ett akademiskt ämne med professurer och forskarutbildning. De gamla socialhögskolorna integrerades under

Peter Dellgran, Professor, institutionen för socialt arbete, Göteborgs universitet

Staffan Höjer, Professor, institutionen för socialt arbete, Göteborgs universitet slutet av 1970-talet i den svenska högskolevärlden och blev platsen för denna etablering. Bakom utvecklingen låg flera aktörer och drivkrafter. Även om bilden inte är helt entydig är en vanlig uppfattning att tillkomsten av forskarutbildningarna var resultatet av en politisk process där organiserade yrkesintressen, tillsammans med socialhögskolorna själva, gick hand i hand med välfärdspolitiska ambitioner. Förväntningarna och förhoppningarna var på 
många håll mycket stora. Avsikten var dels att förbättra kunskaperna om de sociala problemen och samhällets sätt att hantera dessa, dels att akademisera och förvetenskapliga det sociala arbetet och därigenom bidra till en professionalisering av yrkesområdet. Socionomutbildningarna och det sociala arbetes yrkespraktik, skulle nu på ett helt annat sätt än tidigare byggas på vetenskaplig grund och inte bara på föreställningar om yrkespraxis och beprövad erfarenhet. Så var det tänkt, åtminstone idealt och initialt. ${ }^{1}$

Efter en något trevande inledning under 1980-talet har ämnet vuxit dramatiskt och blivit en väletablerad del av svensk samhällsvetenskaplig forskning. Från ursprungligen fyra professorer kan vi idag räkna till drygt 45. Åttiotalets fyra forskarutbildningar har blivit elva. Närmare 260 personer har i skrivande stund doktorerat $\mathrm{i}$ ämnet och antalet docenter ökar i rask takt. Samtidigt har de senaste årens snabba ökning av antalet socionomutbildningar och antagna studenter i landet inneburit ett påfallande stort behov av disputerade lärare som produktionen av doktorer med nöd och näppe mäktar att tillgodose (jfr Salonen 2010). Produktionen av vetenskapliga skrifter i form av böcker, rapporter och vetenskapliga artiklar har ökat kraftigt. En strid ström av vetenskapliga rön publiceras numera löpande, vilket förstär-

1 Detta har långt ifrån varit någon isolerad företeelse. En lång rad andra professionsutbildningar har etablerat egen forskning och forskarutbildning. Akademisering och forskningsanknytning uppfattas som en kungsväg mot professionaliseringen av ett yrkesfält. Jämför bara den mångåriga diskussionen om lärarna! ker socionomutbildningarnas legitimitet och möjligheter till forskningsanknytning. Även om relationen mellan forskning och praktik är komplex och ständigt ifrågasatt, kommer man inte förbi att de yrkespraktiker och de organisationer som vill förankra sin verksamhet i vetenskaplig kunskap idag har långt mer att välja på och förhålla sig till än för trettio år sedan. Forskning i socialt arbete är inte längre bara en fråga om politik, det har också blivit en vetenskaplig praktik.

Ämnets etablering och utveckling berör klassiska, perenna och oundvikliga frågor om kunskapsbildning och relationer mellan vetenskap och yrkespraktik. Forskningens inriktning och karaktär är löpande föremål för både debatt och forskningsintresse $\mathrm{i}$ sig, såväl i andra länder som i Sverige (Bl.a. Bäck-Wiklund 1993, Brante 2003, Sunesson 2003). Framför allt i USA finns en rikhaltig litteratur på området (se t.ex. Kirk \& Reid 2002). Under senare år har inte minst den intensifierade debatten om evidensbaserad praktik ytterligare aktualiserat frågan om den akademiska forskningens roll i Sverige. Ytterst handlar det om forskningens autonomi och villkor å ena sidan och politiskt formulerade krav å den andra, men också om föreställningar om hur kunskap produceras, förmedlas och brukas. Dessa föreställningar är ömsom realistiska, ömsom starkt normativa till sin karaktär.

Vi ska i denna artikel behandla en central del i denna utveckling och diskussion, nämligen doktorsavhandlingarna. Avsikten är att beskriva och analysera innehållet i samtliga doktorsavhandlingar i socialt arbete fram till och med 2009. Tanken är att ge en översiktlig bild av innehållet i dessa avhandlingar 
under hela perioden. Av flera skäl kommer vi dock att specialgranska de senaste elva åren. För det första har närmare två tredjedelar av samtliga avhandlingar kommit till under dessa år. För det andra har vi redan tidigare, på ett mer djuplodande sätt, studerat de första 89 avhandlingarna (Bl.a. Dellgran \& Höjer 2000, 2003a). Möjligtvis återspeglar dessutom det senaste decenniets avhandlingar bättre den forskning och vetenskapliga kunskapsproduktion som idag pågår vid de institutioner som har forskarutbildning i socialt arbete.

Intresset för såväl forskarutbildningens innehåll och betydelse som doktorsavhandlingarnas innehåll har vuxit även internationellt, främst i USA och Storbritannien (se t.ex. Lyons 2003, Orme \& Powell 2008, Scourfield \& Maxwell 2010), men även i länder som t.ex. Kanada (Shera 2003) och Taiwan (Shek, Lee \& Tam 2007). Det finns flera skäl till att kartlägga innehållet i just doktorsavhandlingar. Vid sidan om deras roll i kunskapsbildningen inom ett specifikt professionsområde, är doktorsavhandlingen en slutprodukt av samhällets högsta utbildning, eller det som idag i Sverige benämns som utbildning på forskarnivå. Avhandlingen är med andra ord ett kröningsverk som låter oss ana något om forskarutbildningens kvalitet. En godkänd doktorsavhandling renderar en doktorstitel, och utgör därmed ett av akademins mest prestigefulla och symboliskt laddade fenomen. Fortfarande är avhandlingen för många också ett livsverk. En doktorsexamen är dessutom ett slags körkort och en inträdesbiljett om man vill ta sig vidare i den akademiska karriären. Doktorsexamen krävs för anställning som universitetslektor och innebär att man själv- ständigt har möjlighet att söka forskningsmedel hos de stora forskningsråden.

Avhandlingen är också ett resultat av en inomvetenskaplig process och successiv kvalitetsgranskning där perspektiv, frågeställningar, forskningsmetoder, teorier, analyser och slutsatser kritiskt granskas på seminarier, av opponenter och betygsnämnder osv. Detta sker inom relativt formbundna och kollegiestyrda procedurer och ritualer. Om allt fungerar är därför varje enskild avhandling frukten av god och systematisk forskning, godkänd och accepterad av vetenskapssamhället.

En intressant fråga är om doktorsavhandlingarna, likt paradigmatiska reflektorer, därmed också återspeglar kunskapsintressen, metodmässiga strukturer och teoretiska inriktningar inom ett visst ämne. I vilken mån detta är fallet beror på den totala forskningens omfattning och organisering och vilken grad av självständighet och handlingsfrihet som enskilda doktorander har i valet av avhandlingsämne, forskningsmetoder etc. Avhandlingarnas innehåll påverkas av flera faktorer: den enskilde doktorandens intressen, preferenser och eventuella tidigare yrkesbakgrund (särskilt i fallet socialt arbete där många, men inte alla, doktorander har varit yrkesverksamma socionomer); handledarnas forskningsinriktning, kunskaper och intressen; lokala normer och krav som finns på de enskilda institutionerna samt den akademiska kultur, miljö och ämnesmässiga kompetens som präglar dessa. Graden av styrning från utbildningens och handledarens sida varierar mellan olika ämnen och institutioner. Inom delar av medicin och naturvetenskap finns idag en mycket stark styrning efter- 
som många doktorander ofta ingår i större forskargrupper med etablerade forskningsprogram. Frihetsgraderna i socialt arbete är normalt sett långt högre. Ett rimligt antagande är att antalet avhandlingar som t.ex. rör barnavårds- eller omsorgsfrågor ändå bör vara något större på de institutioner där sådana områden är väl representerade bland seniora forskare. I övrigt kan dock doktorandernas något högre grad av självständighet i socialt arbete (jämfört med delar av medicin och naturvetenskap) innebära att avhandlingarna är en sämre indikator på den totala forskningens karaktär.

Ett annat skäl till att granska avhandlingar är att dessa faktiskt svarar för en väsentlig del av den sammanlagda forskningen. Det florerar allmänna uppgifter i debatten om att det generellt skulle handla om en omfattning motsvarande 40 procent. Detta är dock en komplicerad fråga. För det första varierar detta sannolikt mellan olika ämnen och institutioner men också mellan olika perioder. I socialt arbete svarade avhandlingarna för en klart större andel av den totala forskningen i ämnets ungdom då det ännu inte fanns särskilt många seniora forskare jämfört med idag. För det andra beror det på hur man räknar. Sett till antalet vetenskapliga publikationer kan vi t.ex. nämna att doktorsavhandlingarna svarade för omkring 5 procent av dessa under 2009 vid institutionen för socialt arbete vid Göteborgs universitet. ${ }^{2}$ Men frågan blir då hur man ska vikta en avhandling i förhållande till andra publikationer som veten-

2 Enligt Göteborgs universitetsbiblioteks databas över publikationer. skapliga artiklar eller kapitel i forskningsantologier.

Dagens doktorander är därtill morgondagens seniora forskare, vars kunskaper och specialiserade intressen (som man kan ha ärvt av sina handledare) kommer att prägla forskningens framtida inriktning. Ett signum för vetenskapen är en ständig specialisering. Varje enskild forskare och forskargrupp måste, bland annat för att konkurrera om forskningsmedel, välja forskningsfrågor och relevanta problem som kan uppfattas som ett tydligt tillskott till befintlig kunskap om eller inom ett speciellt fält. Om man i sina doktorsstudier har börjat forska inom ett visst område ligger det nära till hands att det också blir inom detta som man fortsätter sin forskningsbana.

\section{Syfte, frågeställningar och avgränsningar}

Artikeln syftar till att beskriva former och innehållet i samtliga doktorsavhandlingar som lagts fram vid forskarutbildningar i socialt arbete i Sverige fram till och med 2009. Det handlar således om en totalundersökning. Följande frågor och aspekter kommer att granskas.

\section{Ämne och frågeställningar}

I vilken utsträckning behandlas olika typer av sociala fenomen, sociala problem och socialpolitiska frågeställningar? Hur vanligt förekommande är studier om organisering av sociala verksamheter eller rättsliga 
aspekter av socialt arbete i olika former? Hur stor del av avhandlingarna handlar om olika former av sociala arbetsmetoder och interventioner på individ-, grupp- eller strukturnivå? I vilken omfattning studeras professionalisering, yrkesvillkor och olika aspekter av kunskapsanvändning? Hur vanligt förekommande är studier av specifika klient- och patientgrupper, och vilka grupper rör det sig om? I vilken mån är avhandlingarna relaterade till de olika praktikområden som konstituerar det sociala arbetets yrkesutövning och organisationstillhörighet? Går det att identifiera vissa praxisfält som förefaller vara mer respektive mindre försörjda vad gäller vetenskaplig kunskap i form av doktorsavhandlingar? Ytterligare en aspekt som kommer att beröras under denna punkt är förekomsten av utvärderingsambitioner.

\section{Forskningsmetoder}

Vilka forskningsmetoder och empiriska material bygger doktorsavhandlingarna på? Hur vanligt förekommande är kvantitativa respektive kvalitativa metoder? Vilka typer av statistiska material insamlas och analyseras och vilka kvalitativa metoder och material används? Hur ofta kombineras kvantitativa metoder med kvalitativa?

\section{Teoretiska utgångspunkter}

Här är grundfrågan vilka typer av teoribildning, begreppsapparater och teoretiska referenser som förekommer i de svenska doktorsavhandlingarna. Hur vanligt före- kommande är t.ex. teori som har ursprung eller hemvist $\mathrm{i}$ andra discipliner och $\mathrm{i}$ vad mån bygger avhandlingarna på teoretiska referenser eller utgångspunkter som härrör från det egna ämnet?

\section{Former}

Avhandlingarna kommer att granskas utifrån två mer formella aspekter; typ med avseende på sammanläggningsavhandling eller monografi, samt språk.

Då samtliga avhandlingar ingår i kartläggningen är det därtill möjligt att undersöka förekomsten av utvecklingstendenser och förändringar över tid. Har t.ex. inslaget av sammanläggningsavhandlingar som bygger på internationellt publicerade vetenskapliga artiklar på engelska ökat? Går det att identifiera lokala skillnader $\mathrm{i}$ ämnesorientering, metodanvändning etc. mellan de olika lärosäten som har forskarutbildning i socialt arbete?

Vår ambition är i första hand deskriptiv - att beskriva mönster i ämnesval, metoder och teoretiska utgångspunkter. Vi kommer inte i någon större utsträckning diskutera vare sig vilka faktorer som ligger bakom dessa mönster eller vilka implikationer de kan ha för den fortsatta ämnesutvecklingen eller för det sociala arbetes praktik.

Det är värt att understryka att vi inte heller kommer att bedöma eller uttala oss om avhandlingarnas kvalitet. En viktig anledning är att vi för de senaste tio årens avhandlingar har begränsat vår läsning till abstracts (se nedan). Kvalitetsbedömningar är därmed omöjliga. Dessutom är frågan om vad som är bra respektive mindre bra 
mycket komplex och måste alltid vila på normativa uppfattningar om vad som utmärker god forskning och bra avhandlingar. Annan forskning har visat att sådana bedömningskriterier varierar både mellan och inom olika discipliner och forskningsområden. I vissa fall värdesätts t.ex. teoretisk excellens medan man i andra fall betonar metodskicklighet (se t.ex. Nilsson 2009).

\section{Metod och genomförande}

Kartläggningen bygger på de klassificeringsmetoder som vi har utvecklat i samband med tidigare analyser av doktorsavhandlingarna (fram t.o.m. 1998, se Dellgran \& Höjer 2000, 2003c), examensarbeten från socionomutbildningarna (Dellgran \& Höjer 1999a, 1999b) samt forskning genomförd av disputerade forskare inom ämnet socialt arbete (på uppdrag av FAS och HSV $i$ anslutning till en större utvärdering av ämnet socialt arbete 2003, se t.ex. Dellgran \& Höjer 2003a). I enkla ordalag består metoden av en kvalificerad klassificering och kodning av respektive avhandling med avseende på de aspekter som beskrivits ovan. Ansatsen och konstruktionen av instrument finns i sin helhet beskriven och diskuterad i bl.a. Dellgran \& Höjer (2000). De första 89 doktorsavhandlingarna har vi granskat vid tidigare tillfällen och har därför redan tillgängliga data om. Analysen av återstoden utgår i huvudsak på en genomgång av s.k. abstracts.

Att studera mönster med hjälp av kategoriseringar (vilka presenteras i den löpande texten) är förenad med vissa pro- blem. Kategorier är förvisso nödvändiga för att bringa en viss ordning. Men för det första är valda kategorier - hur genomtänkta de än är - långt ifrån självklara. Val av vissa kategorier innebär ett bortval av andra tänkbara vilket riskerar att dölja andra mönster. För det andra är vårt tillvägagångssätt att utgå från t.ex. dominerande ämne stundtals besvärligt eftersom många avhandlingar berör flera ämnesområden. Ett typexempel är avhandlingar som handlar om någon form av det vi här har benämnt som sociala arbetsmetoder (t.ex. hur man på socialkontoren hanterar anmälningar om barn som far illa), men som också kan innehålla en hel del material om hur dessa verksamheter är organiserade. Vi kommer längre fram se att renodlade organisationsstudier är relativt ovanliga men att just intresset för organisatoriska frågor ändå återfinns i många avhandlingar.

När det gäller frågan om hur avhandlingarna har utvecklats över tid har vi valt att dela in hela perioden i tre delperioder: 1980-1998, 1999-2004 respektive 20052009. En fördel har då blivit att antalet avhandlingar inom respektive period är någorlunda lika stort $(89,84$ respektive 80 avhandlingar). Beträffande jämförelsen av de olika institutionerna har vi valt att slå samman de yngre forskarutbildningarna till en övrig kategori eftersom dessa sammantaget enbart svarar för femton avhandlingar av totalt 164 från perioden 1999-2009.

En viktig begränsning för vår analys är att vi har utgått från abstracts. Dessa varierar på flera sätt: omfång, karaktär, betoning $\mathrm{mm}$. Någon enhetlig mall verkar inte finnas vare sig på lokal eller på nationell nivå. Vissa är informationsrika på många punk- 
ter, andra är sparsmakade på det mesta. Särskilt knapphändiga är många när det gäller att beskriva teoretiska utgångspunkter. Kanske är detta också vår första (och kvalitetspräglade!) slutsats av denna kartläggning: abstracten borde kunna vara långt mycket bättre. Även om de naturligtvis inte är skrivna för våra specifika ändamål så har de ett viktigt och självständigt informationsvärde för alla som letar efter tillgänglig forskning inom ett specifikt område.

\section{Former: typ av avhandling och språk}

När det gäller avhandlingarnas form ska vi här begränsa oss till att undersöka dels i vilken utsträckning det handlar om monografier respektive sammanläggningsavhandlingar, dels vilket språk som används. En monografi kan bäst beskrivas som en sammanhängande rapport med specifika kapitel som följer en viss logisk och praxisbunden ordning (i socialt arbete vanligtvis omfattandes mellan 200 och 300 sidor). Inledningsvis introduceras ämne, forskningsproblemet (eller problemen), syften och frågeställningar. Bakgrund och motivering till ämnesvalet presenteras och avhandlingen placeras in $i$ ett forskningsfält, bl.a. genom att tidigare forskning på området gås igenom. Därefter beskrivs och diskuteras teoretiska och metodmässiga utgångspunkter och ansatser. I en slags idealmodell följer sedan en mer resultat- och analysorienterad del för att avslutas med slutsatser. Inom ramen för en sådan modell finns naturligtvis variationer, men det råder generellt sett en relativt stor formbunden- het när det gäller den textmässiga organiseringen av en avhandling.

Sammanläggningsavhandlingen består av ett antal självständiga artiklar som var för sig skickas in för publicering i vetenskapliga tidskrifter. Dessa granskas och godkänns inom ramen för respektive tidskrifts egna bedömningsprocedurer (enligt ett s.k. peer-reviewsystem). Normalt sett hinner inte alla artiklar bli godkända eller publicerade innan sammanläggningsavhandlingen anmäls för disputation, men det finns ofta lokala krav på att ett visst antal ska vara publicerade. Artiklarna innehåller var och en för sig, men i mer begränsad form, alla de komponenter som monografin består av (frågeställningar, teori, metod, resultat etc.). Vetenskapliga artiklar är idag inom många ämnen och forskningsområden mycket formbundna och regelstyrda. Till sammanläggningsavhandlingen fogas sedan en så kallad "kappa" (eller ram) med avsikt att binda ihop de olika artiklarna. Det finns stora skillnader mellan olika ämnen hur dessa avhandlingar de facto ser ut, t.ex. när det gäller kappans omfång, antalet ingående artiklar, vilka regler som gäller vid samförfattade alster osv. I fallet med socialt arbete består de normalt sett av fyra artiklar och en kappa på 50-80 sidor. En kappa finns alltid, men ibland kan sammanläggningen bestå av t.ex. en tidigare publicerad rapport eller licentiatuppsats och ett par artiklar.

Som bekant finns det mycket stora skillnader mellan olika ämnen när det gäller publiceringsformer. Sammanläggningsavhandlingen och artikelformatet dominerar stort inom naturvetenskap, teknik och medicin men är extremt sällsynt inom 
humaniora. På den samhällsvetenskapliga sidan rymmer t.ex. ämnen som psykologi, sociologi, statsvetenskap idag både monografiska och artikelbaserade traditioner. Av de 164 avhandlingar som publicerades i socialt arbete under perioden 19992009 var närmare 73 procent monografier. Av Tabell 1 framgår dock att det finns en tendens att sammanläggningsavhandlingarna blir allt vanligare. Under perioden 2004-2009 motsvarade dessa närmare 40 procent. Det finns stora lokala variationer. Sammanläggningsavhandlingarna är t.ex. klart mer sällsynta i Lund medan de i Stockholm svarar för närmare hälften av alla avhandlingar under det senaste decenniet.

Språkfrågan hänger delvis samman med avhandlingstyp. Det är klart vanligare att avhandlingar som bygger på artiklar är skrivna på engelska. Det sammanhänger i sin tur med de allmänna strömningar, normer och ökade krav som finns inom universitetsvärlden på att forskare ska publicera sig internationellt. Klart är att internationell publicering har ett mycket högre inomakademiskt meritvärde. Som framgår av Tabell 2 var drygt 17 procent av avhandlingarna i socialt arbete under perioden 1999-2009 på engelska. Även här kan vi skönja en viss tendens till ökning, och även här finns lokala skillnader. Var fjärde avhandling i Stockholm under denna period är skriven på engelska medan motsvarande andelar i Göteborg och Lund stannar vid 12-13 procent.

Sammantaget finns det mycket som pekar på att vi kan förvänta oss en fortsatt ökning av avhandlingar som bygger på engelskspråkiga artiklar i vetenskapliga tidskrifter, vilket ställer en viktig och mer generell fråga om möjligheterna till spridning av forskning till aktörer utanför vetenskapssamhället. Det handlar kanske inte i

\section{Tabell I.}

Doktorsavhandlingar i socialt arbete 1999-2009 med avseende på typ, tidsperiod och institution, antal och procentuell fördelning.

\begin{tabular}{|c|c|c|c|c|c|c|}
\hline & \multicolumn{2}{|c|}{ Monografi } & \multicolumn{2}{|c|}{ Sammanläggning } & \multicolumn{2}{|c|}{ Totalt } \\
\hline & antal & $\%$ & antal & $\%$ & antal & $\%$ \\
\hline \multicolumn{7}{|l|}{ Period: } \\
\hline 1999-2004 & 70 & 83,3 & 14 & 16,7 & 84 & 100,0 \\
\hline $2005-2009$ & 49 & 61,2 & 31 & 38,8 & 80 & 100,0 \\
\hline \multicolumn{7}{|l|}{ Institution: } \\
\hline Göteborg & 32 & 78,0 & 9 & 22,0 & 41 & 100,0 \\
\hline Lund & 42 & 93,3 & 3 & 6,7 & 45 & 100,0 \\
\hline Stockholm & 21 & 52,5 & 19 & 47,5 & 40 & 100,0 \\
\hline Umeå & 15 & 65,2 & 8 & 34,8 & 23 & 100,0 \\
\hline Övriga* & 9 & 60,0 & 6 & 40,0 & 15 & 100,0 \\
\hline Samtliga & 119 & 72,6 & 45 & 27,4 & 164 & 100,0 \\
\hline
\end{tabular}

* Örebro, Växjö, Mittuniversitetet/Östersund 
första hand om den rent språkliga tillgängligheten utan snarast om möjligheterna för yrkesverksamma och verksamhetsansvariga politiker och tjänstemän att hålla sig à jour med den inomakademiska tidskriftsvärlden.

\section{Ämnesinriktningar}

Vi ska i det följande beskriva vad de svenska doktorsavhandlingarna i socialt arbete handlar om. Utgångspunkten är hur de fördelar sig på olika ämnesområden. För ändamålet utgår vi från två olika kartor. Båda dessa är utvecklade i samband med tidigare studier och är hierarkiskt uppbygga, vilket möjliggör mönsterbeskrivningar på olika aggregeringsnivåer. Den första tar sin utgångspunkt i vilken utsträckning respektive avhandling till sitt dominerande innehåll är hänförbar till fyra huvudkategorier: (1) studier av sociala företeelser och fenomen, sociala problem och/eller socialpolitik, (2) studier av socialrättsliga och/eller organisationsfrågor, (3) studier av olika sociala arbetsmetoder och organiserade insatser, samt (4) studier av särskilda klientgrupper. Den första kategorin är i sin tur uppdelad på just sociala fenomen, sociala problem respektive studier av olika välfärds- och socialpolitiska system (familjepolitik, arbetsmarknadspolitik, socialförsäkringssystemen, alkohol- och narkotikapolitik, äldrevårdspolitik etc.). På motsvarande sätt är den andra kategorin i sin tur uppdelad i studier med socialrättslig betoning respektive studier där organisatoriska frågor är huvudfokus. Inom kategorin sociala arbetsmetoder återfinns dels en uppdelning med avseende på om dessa studier handlar om metoder på individ-, grupp-

Tabell 2.

Doktorsavhandlingar i socialt arbete 1999-2009 med avseende på språk, tidsperiod och institution, antal och procentuell fördelning.

\begin{tabular}{|c|c|c|c|c|c|c|c|c|}
\hline & \multicolumn{2}{|c|}{ Enbart svenska } & \multicolumn{2}{|c|}{ Enbart engelska } & \multicolumn{2}{|c|}{ Övriga* } & \multicolumn{2}{|c|}{ Totalt } \\
\hline & antal & $\%$ & antal & $\%$ & antal & $\%$ & antal & $\%$ \\
\hline \multicolumn{9}{|l|}{ Period: } \\
\hline 1999-2004 & 66 & 78,6 & 13 & 15,5 & 5 & 6,0 & 84 & 100,0 \\
\hline 2005-2009 & 59 & 73,8 & 16 & 20,0 & 5 & 6,3 & 80 & 100,0 \\
\hline \multicolumn{9}{|l|}{ Institution: } \\
\hline Göteborg & 32 & 78,0 & 5 & 12,2 & 4 & 9,7 & 41 & 100,0 \\
\hline Lund & 34 & 75,6 & 6 & 13,3 & 5 & $|1|$, & 45 & 100,0 \\
\hline Stockholm & 30 & 75,0 & 10 & 25,0 & 0 & 0 & 40 & 100,0 \\
\hline Umeå & 17 & 73,9 & 5 & 21,7 & I & 4,3 & 23 & 100,0 \\
\hline Övriga & 12 & 80,0 & 3 & 20,0 & 0 & 0 & 15 & 100,0 \\
\hline Samtliga & 125 & 76,2 & 29 & 17,7 & 10 & 6,0 & 164 & 100,0 \\
\hline
\end{tabular}

Peter Dellgran \& Staffan Höjer: Nya trender och gamla mönster. 
eller mer strukturell nivå, dels en underkategori om frågor kring professionalisering, yrkesvillkor och kunskapsfrågor som inte direkt är hänförbara till metoder på olika nivåer. Kategorin särskilda klientgrupper är i sin tur uppdelad i en lång rad olika specifika patient- eller klientgrupper (som dock inte särredovisas i denna artikel).

Vi måste än en gång betona att det är förknippat med en hel del svårigheter att bestämma under vilken kategori en avhandling hör hemma. Utgångspunkten är vilken inriktning som dominerar i respektive avhandling. Då ett antal avhandlingar faktiskt handlar om frågor som berör flera av våra kategorier innebär det en risk för att intresset för, och den faktiska kunskapsproduktionen om, t.ex. olika klientgrupper, organisationsaspekter eller övergripande socialpolitiska frågor på det här viset blir underskattat i vår sammanställning.

Den andra kartan bygger på en indelning av det professionella yrkesfält som sammantaget utgör de praktiskt verksamma socionomernas arbetsmarknad. Indelningen är ursprungligen gjord inom ramen för andra studier som behandlat professionaliseringen av det sociala arbetet (se t.ex. Dellgran \& Höjer 2003b). Även denna karta är hierarkiskt uppbyggd och består på sin mest finfördelade nivå av totalt 24 olika arbetsområden. I denna artikel kommer vi enbart att utgå från sex huvudområden när vi undersöker i vilken mån doktorsavhandlingarna från perioden 1999-2009 kan relateras till specifika avnämarområden. Avsikten med att undersöka hur avhandlingarna är relaterade till olika professionella yrkesområden är dels att avgöra hur stor del av denna forskning som överhuvudtaget har en någorlunda tydlig adressat vad gäller specifika verksamhetsfält, dels att identifiera områden som idag är mer försörjda med avhandlingsforskning än andra. På den sistnämnda punkten kommer vi därför att jämföra antal och andel avhandlingar med hur många yrkesverksamma socionomer som återfinns inom respektive arbetsområde. Uppgifterna för detta har vi hämtat från ett tidigare forskningsprojekt där vi haft anledning att göra en uppdelning av just de yrkesverksamma på olika fält. Det empiriska underlaget utgörs av en enkät till totalt 1000 svarande socionomer (Dellgran \& Höjer 2005).

För att avgöra om avhandlingarna är relaterade till sådana områden har vi använt oss av två principer. För det första har vi gjort en egen bedömning huruvida det finns en direkt och stark innehållsmässig koppling till ett visst arbetsområde. För det andra har vi utgått från om ett visst område finns namngivet i titel eller abstract. Det är viktigt att understryka att vi inte menar att den forskning som inte på detta sätt blir kopplad till specifika arbetsområden inte ska bedömas som relevant och/eller intressant för det praktiska sociala arbetets olika aktörer. Men den är något mer generell till sin karaktär. Det kan gälla kunskaper om problem och interventioner som riktar sig till och/eller kan uppfattas som användbara för alla aktörer oavsett vilket specifikt arbetsområde man opererar inom.

Om vi inledningsvis ser till samtliga doktorsavhandlingar kan vi konstatera att ungefär en tredjedel av dessa har huvudsakligt fokus på frågeställningar som rör olika typer av sociala fenomen, social problem och socialpolitik (se Tabell 3). Denna andel 
har varit stabil under hela perioden. Av de 54 avhandlingar som är hänförbara till denna kategori under perioden 1999-2009 handlar 30 om sociala fenomen, 9 om olika typer av sociala problem medan 18 sysslar med socialpolitiska frågor. Det sistnämnda innebär att totalt 10 procent av avhandlingarna under denna period studerar olika delar av socialpolitiken på ett mer övergripande plan.

Även området sociala arbetsmetoder och insatser motsvarar en tredjedel av samtliga avhandlingar. Men av Tabell 3 att döma verkar det finnas ett ökat intresse över tid. Andelen avhandlingar som på olika sätt studerar någon form av arbetsmetoder ökar med andra ord. Vid en närmare granskning dominerar individrelaterade metoder starkt. Av de 50 avhandlingar som specifikt behandlar arbetsmetoder rör 37 individ- och familjerelaterat arbete, och visar dessutom på en ökning. Vi har också tidigare konstaterat att intresset för att studera arbetsmetoder och verksamheter som är grupp- eller strukturinriktade både är mycket begränsat och minskande.
Detta är måhända också en återspegling av vad som under en lång tid har pågått i det sociala arbetets praktik. Ett tiotal avhandlingar under perioden 1999-2009 rör till sitt huvudsakliga innehåll yrkesvillkor och professions- och kunskapsfrågor.

Av klart mindre omfattning är intresset för socialrättliga och organisationsrelaterade ämnen. Under hela perioden 19802009 har enbart 10 procent av samtliga avhandlingar haft en sådan dominerande inriktning, varav den stora merparten av dessa kan beskrivas som organisationsstudier. Detta innebär att avhandlingar som i huvudsak behandlar socialrättsliga spörsmål är ganska sällsynta. Däremot gäller för både organisations- och rättsfrågorna att dessa berörs i långt fler avhandlingar men då på ett mer avgränsat sätt.

Inslaget av avhandlingar som är centrerade till studier av olika klient- och patientgrupper är relativt stort. Ser man till samtliga avhandlingar motsvarar dessa 23 procent. Däremot finns det tecken på att renodlade studier av specifika klientgrupper minskar, framför allt under de senaste

\section{Tabell 3}

Doktorsavhandlingar $i$ socialt arbete 1980-2009, dominerande ämnes-inriktning med avseende på tidsperiod, procentuella andelar ( $N=253)$.

\begin{tabular}{ccccccc}
\hline & n & $\begin{array}{c}\text { Sociala } \\
\text { fenomen och } \\
\text { problem }\end{array}$ & $\begin{array}{c}\text { Socialrätt } \\
\text { och organi- } \\
\text { sation }\end{array}$ & $\begin{array}{c}\text { Sociala } \\
\text { arbets- } \\
\text { metoder }\end{array}$ & $\begin{array}{c}\text { Klient- } \\
\text { grupper }\end{array}$ & Totalt \\
\hline Period: & & & & & & \\
1980-1998 & 89 & 32,6 & 15,7 & 29,2 & 22,5 & 100 \\
1999-2004 & 84 & 33,3 & 3,6 & 35,7 & 27,4 & 100 \\
2005-2009 & 80 & 33,8 & 10,0 & 37,4 & 18,8 & 100 \\
Samtliga & 253 & 33,2 & 9,8 & 34,1 & 22,9 & 100 \\
\hline
\end{tabular}


tio åren (se Tabell 3). Det största intresset handlar här om funktionshindrade. Av totalt 37 klientfokuserade avhandlingar under perioden 1999-2009 handlar 16 om fysiskt eller psykiskt funktionshindrade personer. Man ska vara försiktig med övertolkningar men vi kan konstatera att avhandlingsintresset för missbrukare och personer med försörjningsstöd är mer begränsat.

I allt väsentligt överensstämmer dessa mönster med de som vi tidigare har funnit när vi studerat ämnesinriktningarna i den seniora forskningen (Dellgran \& Höjer 2003a). Närmare 32 procent av de forskningspublikationer som låg till grund för den analysen koncentrerade sig på olika typer av sociala arbetsmetoder, av vilka individ- och familjeorienterade sådana dominerade stort. Inslaget av forskning om grupp- och strukturorienterade verksamheter var även här mer begränsat. Likaledes var seniora studier med mer renodlad orientering mot organisations- och social- rättsliga frågor av klart mindre omfattning. Däremot visar det sig att forskning om särskilda klientgrupper är klart mindre representerat i senior forskning i jämförelse med avhandlingarna.

Om vi ser till lokala variationer kan vi först konstatera att det relativa intresset för att studera metoder är klart störst i Umeå, närmare hälften av avhandlingarna under perioden 1999-2009 har här fokuserat på olika typer av sociala arbetsmetoder (se Tabell 4). På motsvarande vis har klientgruppsrelaterade studier relativt sett varit mest förekommande i Göteborg, medan inslaget av studier av sociala arbetsmetoder varit mer begränsat här.

Innan vi går över till att se hur avhandlingarna är relaterade till yrkesområden ska vi nämna något om inslaget av utvärdering. Utgångspunkten är här att vi har granskat vilka avhandlingar som i någon mån, t.ex. som en delfrågeställning, syftat till att utvärdera t.ex. effekterna av vissa arbetsmetoder. Här handlar det således inte

\section{Tabell 4.}

Doktorsavhandlingar $i$ socialt arbete 1999-2009, dominerande ämnes-inriktning med avseende på institution, antal $(N=164)$.

\begin{tabular}{lccccc}
\hline & n & $\begin{array}{c}\text { Sociala feno- } \\
\text { men eller } \\
\text { problem }\end{array}$ & $\begin{array}{c}\text { Socialrätt } \\
\text { eller organisa- } \\
\text { tion }\end{array}$ & $\begin{array}{c}\text { Sociala } \\
\text { arbets- } \\
\text { metoder }\end{array}$ & $\begin{array}{c}\text { Klient- } \\
\text { grupper }\end{array}$ \\
\hline Göteborg & 41 & 15 & 2 & 11 & 13 \\
Lund & 45 & 16 & 3 & 18 & 8 \\
Stockholm & 40 & 13 & 4 & 15 & 8 \\
Umeå & 23 & 6 & 2 & 11 & 4 \\
Övriga* & 15 & 5 & 0 & 5 & 5 \\
Samtliga & 164 & 55 & 11 & 60 & 38 \\
\hline
\end{tabular}

*Örebro, Växjö och Mittuniversitetet/Östersund 
längre om avhandlingarnas huvudfokus. I det stora hela kan man räkna avhandlingar som haft utvärdering som huvudfokus på ena handens fingrar. Renodlade utvärderingar är således mycket sällsynta.

Utvärderingsambitioner återfinns i 11 procent av samtliga avhandlingar från perioden 1999-2009. Eftersom många avhandlingar inte specifikt handlar om sociala arbetsmetoder kan det vara mer rimligt att se hur stor andel av avhandlingar med sådant fokus som också sysslar med någon grad av utvärdering. Det visar sig då att 20 procent av alla avhandlingar som är koncentrerade till att studera någon form av sociala arbetsmetoder har ett visst inslag av utvärderande frågeställningar. Ser vi till avhandlingar som studerar individoch familjerelaterade arbetsmetoder ökar denna andel till 25 procent. När det gäller lokala skillnader utmärker sig återigen Umeå och Göteborg. Umeå har den klart största andelen avhandlingar med utvärderingsinslag medan Göteborg på motsvarande vis har den i särklass lägsta. Delvis beror detta på skillnader i andelen avhandlingar som studerar sociala arbetsmetoder. Vi kan också konstatera en påtaglig ökning av inslaget av utvärdering. Andelen avhandlingar med någon grad av utvärderingsambition är mer än dubbelt så stor under den senaste femårsperioden i jämförelse med åren 1999-2004, från 7 till 15 procent.

Nästa steg handlar om att undersöka i vilken utsträckning avhandlingarna går att relatera till olika yrkes- och verksamhetsrelaterade arbetsområden. Som vi redan nämnt bygger detta på en indelning som totalt omfattar 24 olika sådana områden. I Tabell 5 är dessa sammanslagna till fem namngivna områden och ett övrigt. Detta innebär att social omsorg innefattar såväl äldreområdet som funktionshinderområdet, att missbrukarvård respektive social barnavård täcker såväl institutionsvård, socialkontorsarbete samt annat öppenvårdsarbete. Försörjningsstöd innefattar både socialkontorens hantering av socialbidrag och annat försörjningsrelaterat stöd inom andra verksamheter (t.ex. inom det arbetsmarknadspolitiska fältet och rehabiliteringen).

Drygt tre fjärdedelar av samtliga avhandlingar från perioden 1999-2009 har en tydlig områdesrelaterad adressat. Omkring 25 procent av avhandlingarna går således inte att koppla till ett specifikt verksamhetsområde. Social omsorg är på det här viset bäst försörjt med avhandlingsforskning. Var femte avhandling är specifikt relaterad till det sociala omsorgsfältet. Dessa fördelar sig i det närmaste helt jämnt mellan äldreomsorg respektive handikappomsorg. Det näst störst området utgörs av den sociala barn- och ungdomsvården (14 procent av samtliga avhandlingar) medan missbrukarvården omfattar 9 procent och försörjningsstöd och hälsovårdsområdet omfattar vardera 7 procent av det totala antalet avhandlingar. Som också framgår av Tabell 5 är däremot inslaget av avhandlingar som är relaterade till t.ex. skola och kriminalvård mycket mer begränsat. Värt att notera är att det finns en del avhandlingar i övrig kategorin som studerar frågor som går att relatera till individ- och familjeomsorgsverksamhet på socialkontoren men som inte specifikt är inriktad på missbrukarvård, barnavård eller försörjningsstöd.

Om vi gör en ytterligare indelning av 
perioden 1999-2009, kan vi skönja tecken på att intresset för social barnavård ökar under den senaste tioårsperioden och att orienteringen mot missbrukarvård och försörjningsstöd på motsvarande vis minskar. Andelen avhandlingar som är relaterade till de två sistnämnda halveras faktiskt mellan de två delperioderna 1999-2004 respektive 2005-2009. Det är svårt att med vårt material säga om detta innebär ett bestående trendbrott.

Ser vi till lokala skillnader kan vi notera att omsorgsrelateringen relativt sett har sitt starkaste fäste i Umeå, att relateringen till sociala barnavården är störst i Göteborg och Stockholm, och att missbruksorienteringen är klart mest förekommande i Stockholm. Vidare är intresset klart störst i Lund och Stockholm när det gäller försörjningsstöd. När det gäller hälsoområdet lyser Stockholm starkast - hälften av alla avhandlingar som under perioden 1999-2009 kan relateras till området är skrivna vid Stockholmsinstitutionen.

\section{Tabell 5.}

Doktorsavhandlingar i socialt arbete 1999-2009 fördelade på yrkesområde, ämnesinriktning samt utvärderingsinslag.

\begin{tabular}{|c|c|c|c|c|c|c|c|c|}
\hline \multirow[t]{2}{*}{$\begin{array}{l}\text { Yrkes- } \\
\text { område }\end{array}$} & \multirow[t]{2}{*}{$\mathbf{n}$} & \multirow[t]{2}{*}{$\begin{array}{c}\text { Andel } \\
\text { i \% }\end{array}$} & \multicolumn{4}{|c|}{ Antal med fokus på: } & \multirow{2}{*}{$\begin{array}{c}\text { Antal } \\
\text { med } \\
\text { inslag } \\
\text { av } \\
\text { utvär- } \\
\text { dering }\end{array}$} & \multirow{2}{*}{$\begin{array}{c}\text { Andel } \\
\text { yrkes- } \\
\text { verk- } \\
\text { samma } \\
\text { sociono- } \\
\text { mer i \%** }\end{array}$} \\
\hline & & & $\begin{array}{c}\text { Förete- } \\
\text { elserl } \\
\text { pro- } \\
\text { blem }\end{array}$ & $\begin{array}{c}\text { Juridik/ } \\
\text { organi- } \\
\text { sation }\end{array}$ & $\begin{array}{l}\text { Meto- } \\
\text { der }\end{array}$ & $\begin{array}{c}\text { Klient- } \\
\text { grup- } \\
\text { per }\end{array}$ & & \\
\hline Omsorg & 33 & 20,1 & 5 & 2 & 15 & 11 & 2 & 8,0 \\
\hline $\begin{array}{l}\text { Social } \\
\text { barnavård }\end{array}$ & 23 & 14,0 & 4 & । & 15 & 3 & 5 & 23,4 \\
\hline $\begin{array}{l}\text { Försörjnings- } \\
\text { stöd }\end{array}$ & 15 & 9,1 & 6 & 3 & । & 2 & 3 & 13,3 \\
\hline $\begin{array}{l}\text { Missbrukar- } \\
\text { vård }\end{array}$ & 12 & 7,3 & 2 & । & 6 & 6 & । & 6,9 \\
\hline $\begin{array}{l}\text { Hälso- och } \\
\text { sjukvård }\end{array}$ & 12 & 7,3 & 3 & 0 & I & 8 & 2 & 15,9 \\
\hline Övriga* & 29 & 17,7 & 4 & 4 & 16 & 5 & 4 & 32,5 \\
\hline $\begin{array}{l}\text { Totalt med } \\
\text { stark koppling }\end{array}$ & 124 & 75,6 & 24 & 11 & 54 & 35 & 17 & \\
\hline $\begin{array}{l}\text { Utan stark } \\
\text { koppling }\end{array}$ & 40 & 24,4 & 32 & 0 & 5 & 3 & । & \\
\hline Samtliga & 164 & 100,0 & 56 & 11 & 59 & 38 & 18 & 100,0 \\
\hline
\end{tabular}


I Tabell 5 kan också några andra intressanta iakttagelser göras. Det handlar om relativt stora skillnader inom dessa områdesrelateringar med avseende på vad avhandlingar handlar om. På den sociala omsorgssidan är det relativa intresset för arbetsmetoder och insatser, men även klientgruppsstudier, relativt stort. När det gäller social barnavård dominerar intresset för metoder stort (15 av totalt 23 avhandlingar under perioden 1999-2009), medan den relativa orienteringen mot studier av klientgrupper är klart mer begränsad. Inom hälsoområdet är det relativa intresset för metoder av klart mindre omfattning, här handlar det istället om ett mer påtagligt intresse för patientgrupper. Sammantaget kan man säga att metodfrågorna på ett helt annat sätt har fokuserats inom barn- och ungdomsvård och omsorgsområdet medan klienterna har renderat klart större intresse inom den avhandlingsforskning som är relaterad till försörjningsstöd och hälso- och sjukvårdsområdet.

Vi kan också konstatera att det sociala omsorgsområdet har gett upphov till fler avhandlingar än det proportionerligt skulle ha gjort om man ser till antalet yrkesverksamma socionomer. För två områden hälso- och sjukvård respektive barn- och ungdomsvård - gäller det motsatta. I båda dessa fall överstiger andelen yrkesverksamma klart andelen avhandlingar som kan relateras till dessa områden. Det är dock viktigt att påpeka att andelen yrkesverksamma socionomer inom ett visst område inte ensamt kan säga något om respektive områdes reella socialpolitiska betydelse. Inte heller finns det något självklart sätt att göra en bedömning av hur mycket befintlig forskning som motsvarar kunskapsbehoven inom enskilda områden. Men jämförelsen ger vissa indikationer och bör kunna vara föremål för fortsatta diskussioner om framtida forskningsbehov och vetenskaplig kunskapsförsörjning.

Det kan vara värt att nämna att i den genomgång av senior forskning i socialt arbete som vi gjorde för några år sedan så framträdde i princip samma bild (Dellgran \& Höjer 2003a). De yrkesområden som på det här viset framstod som bäst försörjda med forskning var omsorg, missbrukarvård samt social barnavård. Både inom omsorgsområdet och den sociala barnavården var det relativa intresset för just verksamheterna och arbetsmetoderna större än på t.ex. missbruks- och försörjningsområdet. På de sistnämnda områdena förekommer relativt sett istället både mer forskning kring missbruk respektive fattigdom som sociala problem och studier av klientgrupperna. Intresset för att studera organisation och arbetsmetoder inom försörjningsområdet framstår på det här viset som särskilt begränsat med tanke på verksamhetens totala omfattning. Vår slutsats då var att den seniora forskningen dels är ojämnt fördelad på olika verksamhets- och arbetsområden, dels obalanserad med avseende på vilken typ av kunskap som produceras.

\section{Forskningsmetoder}

I samtliga abstracts utom ett finns det uppgifter om vilken typ av forskningsmetoder som använts i doktorsavhandlingarna. Det framstår med andra ord som en uppgift som författarna anser bör finnas med. 
Emellertid presenteras endast i knappt hälften av de studerade abstracten några detaljerade uppgifter om hur många intervjuer, enkäter, dokument etc. som avhandlingen bygger på. Sammantaget bygger nästan sex av tio avhandlingar på kvalitativa forskningsmetoder (se Tabell 6) . Var tredje är genomförd med en kombination av kvantitativa och kvalitativa metoder medan 12 procent enbart baseras på kvantitativa metoder. De senaste fem åren har andelen kvantitativa doktorsavhandlingar ökat, särskilt jämfört med femårsperioden dessförinnan då mindre än 5 procent av avhandlingarna utgick från kvantitativt material.

Män använder oftare enbart kvantitativa metoder än kvinnor, medan kvinnor oftare använder en kombination av metoder eller enbart kvalitativa (se Tabell 7). Det finns också påtagliga skillnader mellan olika institutioner. I Stockholm är fördelningen ganska jämn mellan avhandlingar som bygger på kvantitativa, kombinerade eller kvalitativa metoder. I Göteborg, Lund och Umeå dominerar de kvalitativa metoderna klart. I Umeå har vi inte funnit någon avhandling som är skriven utifrån enbart kvantitativa forskningsmetoder under de senaste elva åren. Och i Lund bygger tre av fyra avhandlingar enbart på kvalitativa forskningsmetoder.

I sin helhet finns det inget tydligt samband mellan ämnesområde och forskningsmetod. En intressant iakttagelse är att endast åtta procent av de avhandlingar som fokuserar på sociala arbetsmetoder enbart använder kvantitativa data. Det är vanligare att avhandlingar som inte relaterar till ett specifikt yrkesfält använder kvantitativ metod än bland dem som relaterar till ett sådant.

Det finns ett starkt samband mellan avhandlingsform och användningen av forskningsmetoder. Sammanläggningsavhandlingar och avhandlingar skrivna enbart på engelska är mycket oftare baserade på kvantitativt material jämfört med monografier och avhandlingar på svenska. Avhandlingar som har någon form av utvärderingsambitioner i sitt syfte eller i någon frågeställning bygger lika ofta på kvantitativa metoder som kvalitativa.

När det gäller mer specifika forskningsmetoder har den kvalitativa intervjun en klart dominerande position. I hela 70 procent av avhandlingarna används kvalitativa intervjuer. I 35 procent används någon

\section{Tabell 6.}

Doktorsavhandlingar $i$ socialt arbete 1980-2009 med avseende på forskningsmetoder, antal och procentuell fördelning.

\begin{tabular}{|c|c|c|c|c|c|}
\hline & $\mathbf{n}$ & Kvantitativ & Kombinerad & Kvalitativ & Totalt \\
\hline Samtliga & 253 & 12,2 & 30,4 & 57,3 & 100 \\
\hline \multicolumn{6}{|l|}{ Period } \\
\hline 1980-1998 & 89 & 14,0 & 36,0 & 50,0 & 100 \\
\hline 1999-2004 & 84 & 4,8 & 27,4 & 67,9 & 100 \\
\hline $2005-2009$ & 80 & 18,8 & 27,5 & 53,8 & 100 \\
\hline
\end{tabular}


form av text-/diskursanalys, 30 procent har använt en surveyundersökning, 20 procent observationer och 9 procent någon slags gruppintervjuer, t.ex. fokusgrupper. Knappt 10 procent använder någon form av sekundärdata.

\section{Teoretisk orientering}

Att kategorisera vetenskapliga produkter efter teorimässig grund i ett så heterogent ämne som socialt arbete är ett mycket

\section{Tabell 7.}

Doktorsavhandlingar $i$ socialt arbete 1999-2009 med avseende på forskningsmetoder, antal och procentuell fördelning.

\begin{tabular}{|c|c|c|c|c|c|}
\hline & $\mathbf{n}$ & Kvantitativ & Kombinerad & Kvalitativ & Totalt \\
\hline Samtliga 1999-2009 & 164 & 11,6 & 27,4 & 61,0 & 100 \\
\hline \multicolumn{6}{|l|}{ Kön* } \\
\hline Man & 62 & 21,0 & 22,6 & 56,5 & 100 \\
\hline Kvinna & 101 & 5,9 & 30,7 & 63,4 & 100 \\
\hline \multicolumn{6}{|l|}{ Institution } \\
\hline Göteborg & 41 & 2,4 & 29,3 & 68,3 & 100 \\
\hline Lund & 45 & 8,9 & 15,6 & 75,6 & 100 \\
\hline Stockholm & 40 & 27,5 & 37,5 & 35,0 & 100 \\
\hline Umeå & 23 & 0 & 30,4 & 69,6 & 100 \\
\hline Övriga*** & 15 & 20,0 & 26,7 & 53,3 & 100 \\
\hline \multicolumn{6}{|l|}{ Ämne } \\
\hline $\begin{array}{l}\text { Sociala problem o } \\
\text { fenomen/socialpolitik }\end{array}$ & 55 & 14,5 & 27,3 & 58,2 & 100 \\
\hline Socialrätt/Organisation & $\mid 1$ & 9,1 & 27,3 & 63,6 & 100 \\
\hline Sociala arbetsmetoder & 60 & 8,3 & 31,7 & 60,0 & 100 \\
\hline Klientgrupper & 38 & 13,2 & 27,4 & 65,8 & 100 \\
\hline \multicolumn{6}{|l|}{ Relaterad till yrkesfält } \\
\hline $\mathrm{Ja}$ & 124 & 9,7 & 29,8 & 60,5 & 100 \\
\hline Nej & 39 & 17,9 & 20,5 & 61,5 & 100 \\
\hline \multicolumn{6}{|l|}{ Avhandlingstyp } \\
\hline Monografi & 119 & 6,7 & 21,0 & 72,3 & 100 \\
\hline Sammanläggning & 45 & 24,4 & 44,4 & 31,1 & 100 \\
\hline \multicolumn{6}{|l|}{ Språk**** } \\
\hline Enbart svenska & 125 & 7,2 & 25,6 & 67,2 & 100 \\
\hline Enbart engelska & 29 & 34,5 & 34,5 & 31,0 & 100 \\
\hline \multicolumn{6}{|l|}{ Utvärdering } \\
\hline $\mathrm{ja}{ }^{\circ}$ & 18 & 38,9 & 22,2 & 38,9 & 100 \\
\hline Nej & 144 & 8,3 & 28,5 & 63,2 & 100 \\
\hline
\end{tabular}

${ }^{*}$ En avhandling är skriven av en man och en kvinna tillsammans och ej medräknad i tabellen.

${ }^{* *}$ Mittuniversitetet/Östersund, Växjö, Örebro

${ }^{* * *}$ Endast avhandlingar som enbart är skrivna antingen på engelska eller svenska är medtagna. 
besvärligt företag. Både för att det teoretiska innehållet presenteras och brukas på en lång rad olika sätt, men också för att teorins funktion i förhållande till det empiriska materialet sällan är tillräckligt explicitgjord. Dessutom framstår ämnet i sin helhet som heterogent och pluralistiskt med en hög grad av import av teoretiska perspektiv, begrepp och traditioner från andra ämnen (Dellgran \& Höjer 2003c).

I tidigare studier har vi försökt hantera detta dels genom att notera vilka teoretiska referenser som anges för att få en mer detaljerad bild, dels genom att placera in varje text på en ämnesmässig karta utifrån sin dominerande teoretiska orientering. Det senare för att avgöra hur stort det teoretiska inflytandet är från andra ämnen som t.ex. sociologi eller psykologi.

Just när det gäller att bedöma de teoretiska verktygen blir begränsningarna extra stora när vi utgår från abstracts. Många abstracts har överhuvudtaget ingen beskrivning av avhandlingens teoretiska referensram. Metoder och empiriska resultat framstår således som viktigare att förmedla än teoretiska utgångspunkter och överväganden. Vi har nu närmat oss detta genom att för varje avhandling notera de ord med vilka en teoretisk inriktning anges. I vissa fall handlar det om nyckelord som presenteras i abstract, i andra fall har det förekommit begrepp som kan kopplas till ett teoretiskt fält (som t.ex. coping eller social interaktionism). Här kan vi dock inte hävda att det som anges verkligen är en dominerande teoretisk orientering, då vi inte kan avgöra vilken roll de angivna inriktningarna har i avhandlingen. Möjligen skulle man kunna anta att de teoretiska kopplingar som anges i abstract är de som respektive författaren själv anser vara de dominerande, men vi vill varna för att dra för långtgående slutsatser utifrån nedanstående uppgifter.

Den teoretiska orienteringen kunde på ovanstående vis kodas i 141 av avhandlingarna från perioden 1999-2009. Nästan sju av tio avhandlingar hänvisar i sitt abstract till en sociologisk teorigrund. Mindre än en av tio bygger på motsvarande sätt på en teorigrund som domineras av psykologi eller av forskning och teorier som utvecklats inom eller för socialt arbete. Våra tidigare studier har visat att ämnet socialt arbete präglas av pluralism och eklekticism när det gäller teorianvändning men att det sociologiska inflytandet år påfallande stort. Nedanstående lista är inte komplett men utgör exempel på teoretiska hänvisningar som författarna själva angett i abstracts från avhandlingar under perioden 1999-2009. Listan illustrerar med all önskvärd tydlighet den teoretiska heterogenitet som präglar socialt arbete: arbetssociologi, barndomssociologi, emotionssociologi, familjesociologi, kultursociologi, kunskapssociologi, socialpsykologi, handikappteori, diskursteori, diskursanalys, feministisk teori, interaktionism, socialkonstruktivism, symbolisk interaktionism, motivationsteori, nyinstitutionalism, nätverksteori, omsorgsteori, organisationsteori, ungdomsteori, postkolonial teori och professionsteori. Därtill förekommer referenser till teorier om civilsamhället, coping, social exclusion, gender, maskulinitet, human service organizations, modernisering, senmodernitet, quality of life, sexualitet, socialpolitik, socialt arbete, socialt 
medborgarskap, socialt stöd, stigmatisering, utvärdering och välfärd.

Vissa av dessa angivna teoretiska traditioner och inriktningar framstår som mer frekventa än andra. Begrepp som t.ex. har koppling till organisationsteori förekommer i 23 avhandlingar, teori med koppling till kön och sexualitet (feminism, gender, maskulinitet, sexualitet) i 12, social konstruktivism i 10 , socialt stöd i 6 , barndoms- och/ eller familjesociologi i 5. Ibland namnges särskilda teoretiker som kommit att spela en stor roll för analysen. Sålunda återfinns några av sociologins klassiker (Durkheim, Simmel och Tönnies) och mer moderna klassiker som t.ex. Foucault och Goffman. Andra som mycket ofta nämns är Hazenfeldt och Lipsky på det organisationsteoretiska området samt några uttolkare av det senmoderna samhället som t.ex. Bauman och Bech.

\section{Några slutsatser och kommentarer}

Så vad kan då sägas om avhandlingarna i socialt arbete, deras form, ämnesval, forskningsmetoder och teoretiska orientering? Låt oss inledningsvis konstatera att den monografiska dominansen fortfarande är påtaglig men verkar vara på väg att avta något. Bara under den senaste femårsperioden har andelen sammanläggningsavhandlingar fördubblats jämfört med tidigare period. Dessutom ökar inslaget av engelska. På så vis följer socialt arbete den strömning som finns inom den akademiska världen, där publicering i form av vetenskapliga artiklar i internationella tidskrifter premieras framför monografier på svenska. I utvärderingar av forskningsproduktion och i samband med kvalitetsbedömningar och resurstilldelningar används alltid numera olika publicerings- och citeringsanalyser. Dessa utgår från hur mycket av forskningen som utgörs av internationell publicering och i vilken utsträckning den är citerad av andra forskare. Ur meritvärdessynpunkt och av karriär- och konkurrensskäl finns med andra ord incitament för såväl personer som institutioner att publicera sig mer i refereebedömda tidskrifter. Det finns anledning att tro att denna tendens kommer att öka. Samtidigt kan en sådan utveckling göra det svårare för såväl beslutsfattare som praktiskt verksamma socialarbetare att få tillgång till denna forskning.

Ämnesprofilen är alltjämt mycket heterogen och forskningen inom socialt arbete täcker ett mycket brett område och en lång rad olika frågeställningar. Vi har i tidigare skrifter beskrivit ämnet som ett ruralt landskap (få forskare per forskningsområde) men med begynnande tätortstillväxt i termer av specialiseringar (dvs. områden med ökande antal forskare). Exempel på sådana områden är social omsorg och social barn- och ungdomsvård. Detta hänger delvis, men bara delvis, samman med om det finns professurer med speciella inriktningar. Inom dessa områden är antalet avhandlingar, såväl som annan forskning, något mer omfattande och möjligheten att definiera någon form av ackumulerad kunskapsmassa och forskningsfront är därmed något större. Samtidigt finns det verksamhetsområden som verkar vara underförsörjda med forskning. För 
den som vill finna stöd för att det saknas forskning kring vissa fenomen eller frågor finns det med andra ord mycket att hämta. Det finns ingen anledning att utifrån det senaste decenniets avhandlingsproduktion ändra tolkningen av detta huvudmönster. Emellertid ser vi ett något ökat intresse för att studera sociala arbetsmetoder, dock enbart med avseende på individ- och familjeorienterade insatser. Vi ser också en tendens till att allt fler avhandlingar har en tydligare koppling till ett specifikt yrkesområde. Inslaget av utvärderingsambitioner har därtill ökat under de senaste fem åren. Avhandlingsforskningen är sammantaget bred och heterogen och frågan är om ämnet under överskådlig framtid kommer att kunna tillfredsställa alla kunskapsbehov. Därtill är ämnet och dess resurser för begränsat och de potentiella kunskapsbehoven för omfattande.

När det gäller forskningsmetoderna så dominerar fortfarande de kvalitativa metoderna, även om metodvalen präglas av en påtaglig pluralistisk hållning, t.ex. så till vida att många avhandlingsförfattare kombinerar kvantitativa och kvalitativa angreppssätt. Den kvalitativa intervjun är dock den enskilt överlägset mest förekom- mande forskningsmetoden. Vi har tidigare redogjort för ett antal hypoteser (kunskapshypotesen, kulturhypotesen, likhetshypotesen samt den historiska hypotesen) varför detta förhållande föreligger (Dellgran \& Höjer 2000). En ny tendens är dock att renodlade kvantitativa ansatser verkar vara på frammarsch den allra senaste perioden.

Den teoretiska profilen är alltjämt mycket heterogen och eklektisk till sin karaktär, även om vi åter vill betona att våra grunder för att säga något om avhandlingarnas teorianvändning är svagare nu än vid tidigare analyser. Ämnet i sin helhet bygger fortfarande på en hög grad av import av teori med sitt ursprung inom andra delar av samhällsvetenskapen. Helt klart verkar dock vara att författarna inte själva ger teorifrågan lika stor betydelse i sina abstracts som när det gäller ämne, metoder eller empiriska resultat. Och kanske är det den slutsats vi vågar dra: ämnets doktorander bidrar i första hand till att producera empiriska fakta och mindre till teoriutveckling. En måhända provocerande fråga är om detta också gäller för forskningsämnet i sin helhet. Se där en empirisk uppgift som kvarstår? 


\section{Referenser}

Brante T. (2003) Konsolideringen av nya vetenskapliga fält - exemplet forskning i socialt arbete, i Socialt arbete. En nationell genomlysning av ämnet. Högskoleverket Rapport 2003:16.

Bäck-Wiklund M. (1993) Vetenskap och politik, Institutionen för socialt arbete, Göteborgs universitet, Skriftserien 1993:8.

Dellgran P. \& Höjer S. (1999a) Kunskapandets villkor och gestalt. En studie av uppsatser $i$ socionomutbildningen 1977-97. Socialstyrelsen, CUS 1999:1.

Dellgran P. \& Höjer S. (1999b) När studenten själv får välja. Om uppsatser i socionomutbildningen och dess roll för professionaliseringen av det sociala arbetet. Socionomens forskningssupplement, nr. 10, s. 30-48.

Dellgran P. \& Höjer S. (2000) Kunskapsbildning, akademisering och professionalisering $i$ socialt arbete. Institutionen för socialt arbete, Göteborgs universitet.

Dellgran P. \& Höjer S. (2003a) Forskning i praktiken, i Högskoleverket och FAS, Socialt arbete. En genomlysning av ämnet. Högskoleverkets Rapport 2003:16.

Dellgran P. \& Höjer S. (2003b) En delad och ambivalent profession. Socionomers attityder till privatisering av socialt arbete. Socionomens forskningssupplement, $\mathrm{nr}$ 15, s. 17-36.

Dellgran P. \& Höjer S. (2003c) Towards autonomy. On theoretical knowledge in Swedish social work. European Journal of Social Work. Vol 6:2, s. 145-161.

Dellgran P. \& Höjer S. (2005) Rörelser i tiden. Om professionalisering och privatisering i socialt arbete, Socialvetenskaplig tidskrift, nr. 2-3, s. 246-266.
Kirk S. A. \& Reid W. J. (2002) Science and Social Work: A Critical Appraisal. New York: Columbia University Press.

Lyons K. (2003) Doctoral Studies in Social Work: Exploring European Developments. Social Work Education, vol. 22:6, s. 555-64.

Nilsson R. (2009) God vetenskap. Hur forskares vetenskapsuppfattningar uttryckta i sakkunnighetsutlàtanden förändras i tre skilda discipliner. Akad. avh. Göteborgs universitet.

Orme J. \& Powell J. (2008) Building Research Capacity in Social Work: Process and Issues. British Journal of Social Work, vol. 38:5, s. 9881008.

Salonen T. (2010) Det sociala arbetets professionssträvanden - dimensionering, kvalitet och kompetens. Socialvetenskaplig tidskrift, nr.1, s. 92-103.

Scourfield J. \& Maxwell N. (2010) Social Work Doctoral Students in the UK: A Web-Based Survey and Search of the Index to Theses. British Journal of Social Work, 40, s. 548566.

Shek D., Lee J.H. \& Tam S.Y. (2007) Analyses of Postgraduate Social Work Dissertations in Taiwan. International Social Work, vol. 50:6, s. 821-838.

Shera W. (2003) Doctoral Social Work Education in Canada: History, Current Status and Future Challenges. Social Work Education, vol. 22, s. 603-610.

Sunesson . (2003) Socialt arbete - en bakgrund till ett forskningsämne, i Socialt arbete. En nationell genomlysning av ämnet. Högskoleverket Rapport 2003:16. 


\section{Summary}

\section{New trends and old patterns Doctoral dissertations in social work 1980-2009}

Doctoral theses have a special role in academia. Besides producing new scientific knowledge, they normally reflect disciplinary currents and traditions. The aim of this article is to present and analyse the form and content of all Swedish doctoral theses in social work. A total of 253 theses from 1980 to 2009 have been analysed. The results show that some earlier patterns remain. Topics are very heterogeneous, qualitative methods dominate and sociological theory seems to be the major source of analysis. However, new tendencies can also be noted. There is more interest in social work methods, and more theses are based on articles and are written in English. 